\title{
痤攣性発声障害の音声評価
}

$$
\text { 牧山 清1) 熊田 政信 }{ }^{2)} \quad \text { 小林 武夫 }{ }^{3)}
$$

要 約：本研究では痤卛性発声障害 (SD) の重症度を評価する目的で音声評価法を考案し, その有用性について検討した. SD 患者 15 人を対象としたモーラ法の検討では, 聴覚的重症度 が高い患者ではモーラ法のスコアーも高かった。また，経過観察における重症度評価にも有用 であった. 別の SD 患者 15 人を対象として音響学的および空気力学的評価を行った. 朗読時間 に対する無音区間の比率, shimmer, SNR, および flow 標準偏差値と聴覚的重症度との間に有 意の関係が認められた，日常生活の各場面を想定した支障度評価用アンケートを作成し，聴覚 的重症度と比較検討した。その結果，われわれが診察中に把握することができない患者の日常 の支障度を評価することが可能であった。

索引用語：痤攣性発声障害, 音声評価, モーラ法, 無音区間, 日常生活支障度

\section{Voice Assessments in Patients with Spasmodic Dysphonia}

\author{
Kiyoshi Makiyama ${ }^{1)}$, Masanobu Kumada ${ }^{2)}$, Takeo Kobayashi ${ }^{3)}$
}

\begin{abstract}
This study reviewed the usefulness of voice assessment methods for evaluation of the severity of spasmodic dysphonia (SD). The methods reviewed were the mora method, acoustic and aerodynamic analyses, and a questionnaire for patients concerning inconvenience in daily living. There was a strong correlation between results by the mora method and the perceptual rating score. The mora method was useful also for severity assessments during follow-up. The time required to read sentences aloud and the sum of the acoustically silent periods during reading (phonatory breaks) were evaluated. The ratio of the sum of phonatory breaks to reading time (aphonetic time ratio) was also studied. The aphonic time ratio, shimmer, SNR, and standard deviation of the flow correlated significantly with the perceptual rating score, A questionnaire for evaluation of inconvenience in various situations of daily living due to SD was prepared, and its results were compared with the perceptual rating score. Inconvenience experienced by patients in their daily living, some of which cannot be detected during consultations, could be assessed by the questionnaire. From the results obtained, we propose the following parameters for
\end{abstract}

日本大学医学部耳鼻咽喉科学教室 ${ }^{1)}$ : $=101-8309$ 東京都千代田区神田駿河台 1-8-13

東京大学大学院医学系研究科認知言語医学講座音声言語医学教室 ${ }^{21}$ : ₹ 113-0033 東京都文京区本郷 7-3-1

帝京大学市原病院耳鼻咽喉科 ${ }^{3)}$ : $=299-0111$ 市原市姉崎 3426-3

${ }^{1)}$ Department of Otorhinolaryngology-Head and Neck Surgery, School of Medicine, Nihon University : 1-8-13, Kandasurugadai, Chiyoda, Tokyo 101-8309

${ }^{2)}$ Department of Speechphysiology, Graduate School of Medicine, The University of Tokyo:7-3-1, Hongo, Bunkyo, Tokyo 113-0033

${ }^{3}$ Department of Otorhinolaryagolosy, Teikyo University Ichihara Hopital : 3426-3 Anegasaki, Ichihara, Chiba 299-0111

原稿受理 : 2001 年 7 月 11 日 
evaluation of the severity of SD : severity according to perceptual evaluation, time of counting from 1 to 20, time of reading aloud, MPT, mora method, jitter, shimmer, SNR, STD-F0, sum of phonatory breaks, aphonetic time ratio, and the patient's self-evaluation of inconvenience.

Key words : spasmodic dysphonia, voice assessment, mora method, phonatory breaks, inconvenience in daily living

\section{はじめに}

Traube $^{1)}$ の報告以来痙攣性発声障害（spasmodic dysphonia, SD) に関する論文が多く発表されている。 Arnold $^{2}$ は 1959 年に発表した論文の中で表 1 のよう な特徵を持つ疾患を SD と定義している. Aronson は Clinical voice disorders ${ }^{3)}$ の中で, この疾患群を, 内転 型, 外転型, 混合型に分類し, 系統立てて発表した. これらの SD に対する定義や概念は現在でも SD の診 断の参考にされている. SD 患者を客観的に評価しょ うとする試みは 1970 年代から行われており, Wolfe ${ }^{4)}$, Zwitman ${ }^{5}$, Cannito $^{6)}$, Izdebski ${ }^{7}$, Ludlow ${ }^{8)}$, Aron$\mathrm{son}^{3)}, \operatorname{Hartman}^{9}$ らは音響分析手法を用いた報告を行 った。また, Merson ${ }^{10)}$, Aronson ${ }^{11)}$, Hartman ${ }^{12)}$, Davis $^{13)}$, Ludlow ${ }^{14)}$ らは発声機能についての検討を行 つた。彼らの研究により音響学的なまたは発声機能検 查上での SD の特徵が明らかになった. 1980 年代から 米国内の複数の施設でボツリヌストキシン声帯筋内注 入術が行われるようになった。当初，この治療はパイ ロットスタディーとして行われたために，治療効果を 判定する客観的な評価, すなわち重症度評価が必要に なってきた。われわれも同じ理由により重症度評価を 目的として SDに適した定量的な評価法についていく つかの方法を考案してきた.

\section{聴覚的重症度評価法}

本研究を行うにあたり, 日本大学音声喉頭外来の担 当医 3 人による 5 段階の聴覚心理的重症度評価を行
い，検者間の差について検討した。その結果，検者間 で生じる差は 1 段階以下であった。この結果は声帯ポ リープや声帯結節などに対する GRBAS 評価の Gradeの評点における検者間の差と同程度であった。 本研究では熊田らの考案したモーラ法による評価, 牧 山らが試みた音響学的・空気力学的評価, そして共同 で行った患者の自覚的重症度評価案について検討を加 えた。各評価の有用性については, 聴覚心理的重症度 評価との間に適合性があるか否かで判定した。

\section{研究 1 モーラ法による評価}

\section{1. モーラ法について}

疾患の診断の際に，あるいは治療法の効果を記述す る際には客観的評価法が不可欠である ${ }^{15)}$.われわれは $\mathrm{SD}$ の評価法の一つとしてモーラ法を提案している. これは, 患者の朗読文中において, SD に起因すると思 われる症状の出現したモーラ数をもって重症度を表す 方法である ${ }^{16)}$. モーラとは, 日本語に扔ける「拍」のこ とで，各モーラは等時的（時間的に等価）である。基 本的には「(子音十）母音」の構造を持つが, 例外とし て，母音を持たない撥音「ん」や，音そのものにかけ る促音「つ」がある。つまり，五十音表中にあらわれ る各要素とほぼ考えてよい。このようにモーラは, 日 本語発話の時間的かつ音韻的な一つの単位である。し たがって, 症状の出現したモーラを数えるモーラ法は, 患者の発話の達成度の客観的な指標の一つになるとわ れわれは考えている。

\section{表 1 Arnold による痙攣性発声障害の特徵}

1. A voice that is variably squeezed, strained, choked, staccato, stuttering-like, jerky, grunting, groaning, effortful, pinched, grating and has periodic breaks in phonation. It has a tendency to be monopitched and reduced in loudness, and vowels are initiated with hard glottal attacks.

2. The abnormal voice occurs only during voluntary phonation for communication purpose and not during singing, vowel prolongation, laughing, or crying.

3. The abnormal voice is the effect of hyperadduction of the true and false vocal folds.

4. The disorder is caused by psychoneurosis from either occupational stress or emotional trauma, such as family conflicts, accidents, terrifying events, or accumulated frustrations. 
表 2 モーラ法の定義

患者の朗読文中，痓攣性発声障害に起因すると思われる下記症状の出現したモーラ数により，重症度を評価する.

音質レベルの障害：圧迫性努力性の発声，声のとぎれなど

音韻レベルの障害：有声音や母音の無声化, 音素の脱落など

流暢性のレベルの障害: 難発, 反復, 不適切に長い音素など

(注：難発は, 後続モーラの障害とする)

熊田ら(1997) ${ }^{16)}$ より改

\section{2. 方法}

モーラ法は，SD に起因すると思われる症状が出現 したモーラ数の割合を, 朗読文中において求める方法 である。表 2 に，SD に起因すると思われる症状を示 す ${ }^{16)}$. 朗読文としてわれわれは「ジャックと豆の木」を 用いているが，実際に評価に用いるのはそのうち冒頭 の,「むかしあるところに，ジャックという扔とこのこ がいました.」という 25 モーラ文である。

評価者は録音資料を 3 回繰り返し聴いて，症状が出 現したと判断したモーラに記録用紙上で印をつける. 評価者が複数のときは, 過半数の評価者によって印が 付いたモーラを数える.対象は, 1991 年 5 月より 94 年 6 月までの間に東京大学付属病院耳鼻咽喉科音声外来 を受診し SD の確定診断をうけた患者でボツリヌスト キシン声帯筋内注入術を行った 15 名のうち, 初回注射 前後の録音資料のある 10 名 (男女比は 2 対 8 , 注射時 年齢 20 から 71 歳, 平均 35.5 歳) の 37 録音（各患者 あたり 2 から 7 録音) である。

\section{3。モーラ法を用いた評価の具体例}

1 ）ボツリヌストキシン声帯筋内注入術の症状の変 化

図 1 に, ボツリヌストキシン声帯筋内注入術 $14,17 \sim 211$ 後の症状の変化の具体例を示す ${ }^{16)}$. 患者は 39 歳の女性 で，注射後約 3 力月間効果が持続した例であり，ほぼ 典型的な経過を示した 1 例といえよう。注射前，モー ラ法による評価值 (M) は 19/25 であったが，8 月 4 日 注射後, 8 月 9 日には $6 / 25$ まで減少した。その後しば らくほぼ横ばいであったが, 11 月に 12/25 と増加し, 12 月には 22〜 23/25 と, 注射前とほぼ同様にまで戻っ ている.

図 1 中の P は患者自身による主観的評価を表して いる. 注射前と比較して, $\mathrm{P}=3:$ 変化なし. $\mathrm{P}=2:$ 少 しつまりが減った，または少し楽にしゃべれる様にな つた. $\mathrm{P}=1$ ：かなりつまりが減った，またはかなり楽 にしゃべれる様になった， $\mathrm{P}=0$ ：まったくつまりがな くなった,という 4 段階評価法による值である ${ }^{16)}$.この 患者自身の主観的評価 P の推移とモーラ法による評 価值 $\mathrm{M}$ の増減はよく呼応している.

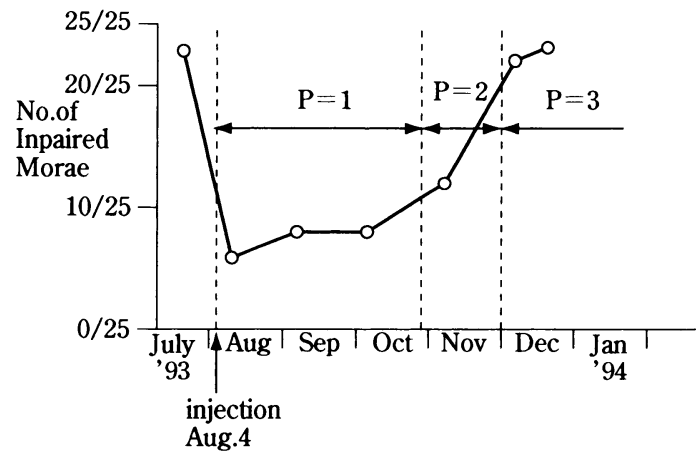

図 1 ボッリヌストキシン声帯筋内注入術前後のモ ーラ法による值 (No. of Impaired Morae) の推移: 39 歳女性の例 (熊田ら ${ }^{16)}$ 上り改). $\mathrm{P}=0-3$ ：患者自身による主観的評価（P= 0 : 症状なし, $\mathrm{P}=1$ : 注射前より非常によ い, $\mathrm{P}=2$ : 注射前より少しょい, $\mathrm{P}=3$ : 注射 前と変化なし)

2 ) 医師による聴覚印象的重症度評価 (D) との比較 モーラ法による值と，録音日同日の外来においての 医師による聴覚印象的重症度評価を比較した。後者に おいては次のような 4 段階評価法を用いた。すなわち， 外来診察中の患者の自由会話においてその発話が $\mathrm{D}=$ $3:$ :びく障害されている. $\mathrm{D}=2$ : 中等度の障害がみ られる. $\mathrm{D}=1$ ：わずかにあるいは軽度の障害がみられ る. $\mathrm{D}=0$ : まったく障害がみられない, という評価で ある ${ }^{16)}$. 図 2 に, 医師による聴覚印象的重症度評価 D の各スケールごとの，モーラ法による評価值 M を示 す，Dが大きくなるほど，M も大きくなる傾向がみら れた。

\section{4. 考察}

具体例に示したごとく, モーラ法は，「聞き手」「話 し手」両者の評価を同時に反映した簡便な客観的評価 法である。その有用性の理由の一つとしては，モーラ の持つ等時性が挙げられると思われる.すなわち, 各 モーラは心理的に等時的であるため, 障害されたモー ラの割合は，発話における「時間的心理量としての障 害の割合」を表していると考えられる。そして，「聞き 


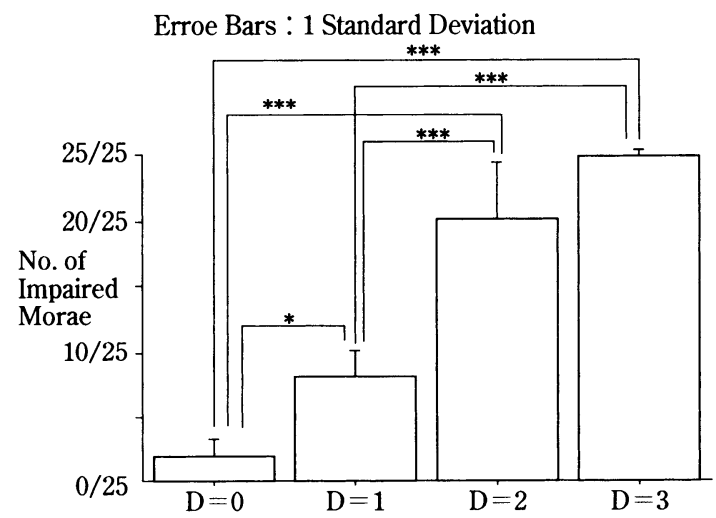

図2 医師による主観的 4 段階重症度評価法の各段 階におけるモーラ法による值（No.of Impaired Morae）の平均（熊田ら ${ }^{16)}$ 上り改）. $\mathrm{D}=0$ 3 : 患者自身による主観的重症度評価 $(\mathrm{D}=$ 0 ：症状なし, $\mathrm{D}=1$ : 軽度, $\mathrm{D}=2$ ：中等度, $\mathrm{D}=3:$ 重度 $), *: \mathrm{p}<0.05, * * *: \mathrm{p}<0.001$

手」「話し手」両者の主観的評価において，この「時間 的心理量としての障害の割合」が強く反映していると われわれは考えている。これに関しては，次の 5 。音 節法も参照していただきたい.

なお, SD の症状は, 決してモーラを単位に出現する わけではない，前述したように，流暢性といった超分 節的な面も障害する。 あくまでも患者の発話の「達成 度」を客観的にしかも簡便に示すことを目的としてわ れわれはこのモーラ法を用いたのである。

\section{5. 音節法 : 英語話者の SD 患者の評価法}

英語においては, 音素に次ぐ最小の単位は音節であ る.そこで, 英語話者の SD の重症度評価としてわれわ れは，モーラ法とパラレルなものとしての「音節法」 を提案している ${ }^{22}$.ただ, 英語発話に扔ける音節には日 本語発話におけるモーラの様な等時性はない。むしろ 英語は, Stress-Timed Rhythm（各ストレスの間隔が 等時的）である。そこで，音節法のタスクとしては， 各音節がモーラの様な等時性を備えた Monosyllabic Full-Stressed Sentences（すべての音節にストレスが おかれている文) を提案している231.

\section{研究 2 音響分析および空気力学的発声機能検査 での評価}

\section{1. 方法}

1 ）流暢性の検討

Silverman ${ }^{24)}$ は SD $を$ acquired fluency disorders と呼んだ。また，SDの症状の特徴として antithetical to fluency, delayed といった言葉が使われている25). これらはわれわれのいう流暢性の障害である。駿河台 日本大学病院を受診した内転型 SD 患者 15 人につい てDAT に録音しておいた患者音声サンプルを利用し て流暢性を反映するパラメーターについて検討した。

(1) 朗読時間

「ジャックと豆の木」の冒頭の文章を読み終えるの に要した時間を測定した。この音声サンプルを録音す る際には，楽な声の大きさ，高さで朗読させ，読むス ピードに関しては特別な指示を与えなかった。

(2) 無音区間

Mac-PC 用音響分析ソフト Sound Scope を用いて 「ジャックと豆の木」の冒頭の文章の朗読中に声が途切 れて無信号となった時間の合計を計算した。

(3) 無音区間比

朗読時間に対する無音区間の比率を計算した。

2 ) 非周期的な変動の検討

SD では発声時に声門㧍よび声門上部構造の非周期 的な過内転または絞厄運動が観察され2,3), discoordinated, interrupted などと表現される症状が出現す る ${ }^{25)}$.一定した持続発声は困難である。この特徴につい ての評価を行った。

(1) 音響分析

声帯振動周期のゆらぎを反映するパラメーターであ る Jitter，振幅のゆらぎを反映するパラメーターであ る Shimmer, 雑音成分比をあらわす Signal to Noise Ratio (SNR) について検討した.さらに声の高さの全 体的な変動について基本周波数標準偏差值 (STD-F 0) を測定することで検討した．音声サンプルの中から持 続発声母音「イ」を米国 GW Instruments 社製音響分 析装置 Sound Scope で読み込み, 発声開始 0.5 秒後よ り 0.5 秒間について計算を行った。

(2) 呼気流量の変動

持続発声中の呼気流量の標準偏差值 (STD-Flow) に ついて検討した. Mac-PC を用いた永島製発声機能検 查装置 PS $77 \mathrm{E}$ による発声機能検査で 1 秒間の呼気流 量を 0.1 秒毎に測定し, その標準偏差値を計算した。

3 ）モーラ法抢よび医師による聴覚的重症度評価と の比較

各検查結果をモーラ法および医師による聴覚的重症 度評価と比較することで各評価法の有用性を検討し た.モーラ法は研究 1 と同じ文章で行った。聴覚的重 症度評価は研究 1 とは異なり, 正常, 軽症, 中等度, 重症扔よびきわめて重症の 5 段階評価を行った。モー ラ法評価において検者間で結果に差が認められた時は サンプルテープを再度聞き直して評価結果を統一し 


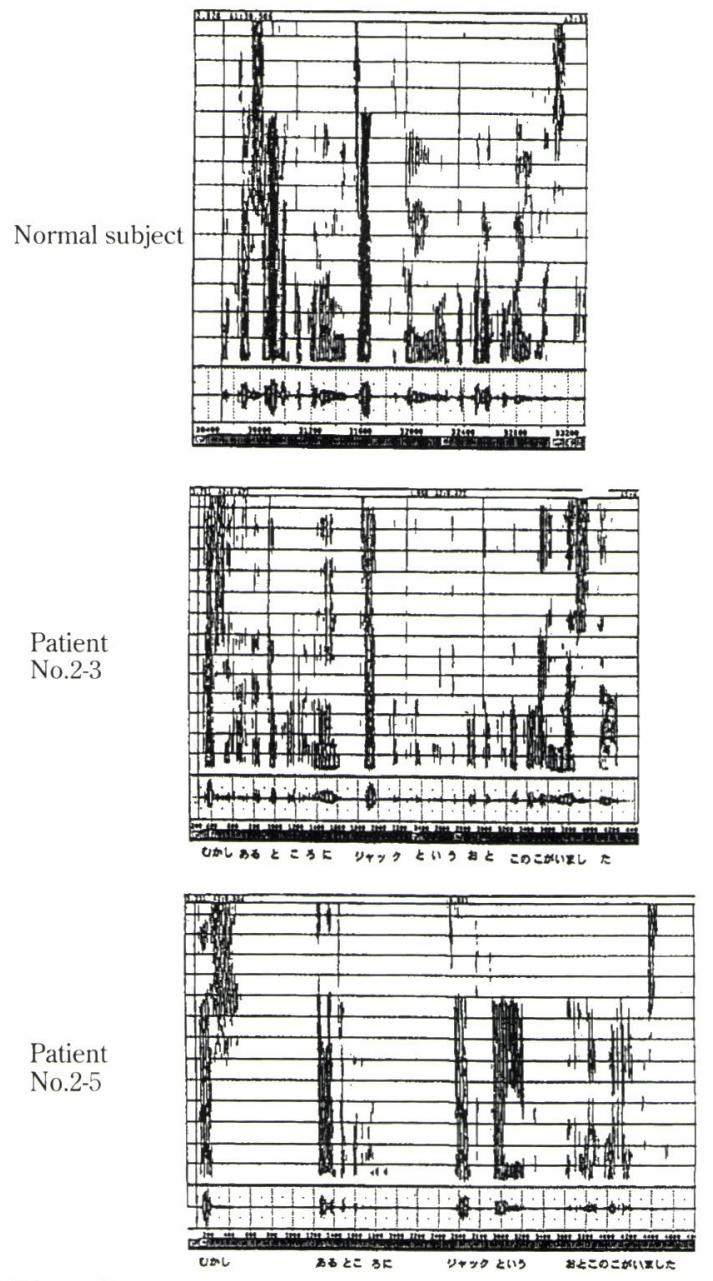

図３「ジャックと豆の木」の冒頭の文章のサウンド スペクトルグラフィー。上より正常例, 症例 $2-3$, 症例 $2-5$.

た。最終的重症度評価点数は各検者の平均値を採用し た。相関関係の検証には Spearman の順位相関法を用 いた。したがって p 值はすべて Spearman 順位補正後 の $\mathrm{p}$ 值を表す。

2. 結果

図 3 は「ジャックと豆の木」の冒頭の文章のサウン ドスペクトルグラフィーである. 正常者に比較すると $\mathrm{SD}$ 患者では朗読中における音声信号が途切れている 時間が長いのが読み取れる。朗読に要する時間も長か

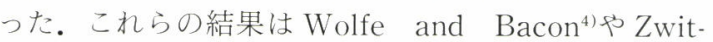
$\mathrm{man}^{5)}$ らが 1970 年代に報告した SD のサウンドスペク トルグラフィー上の特徵と一致する. 図 4 は PS 77 E による発声機能検查結果である. SD 患者の中には正 常パターンを示す例もあったが，大部分の患者では非

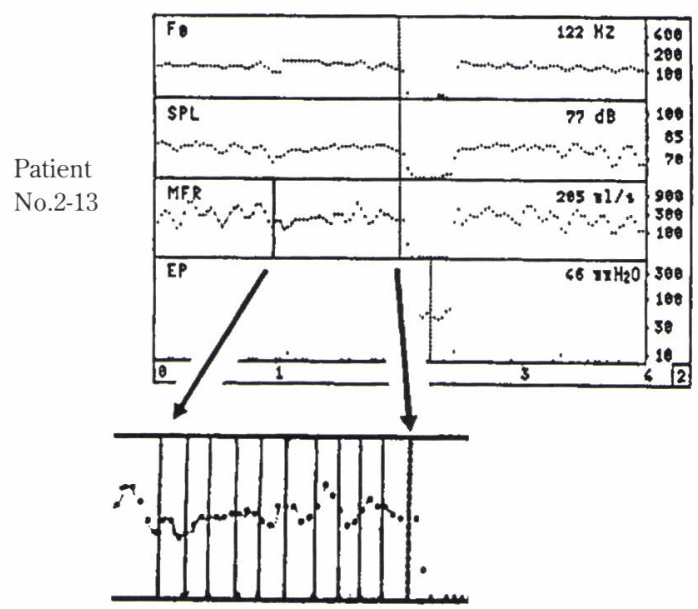

図4 PS 77 E による症例 2-13の発声機能検査結 果. 基本周波数, 音圧, 呼気流率, 特に呼気流 率に非周期的な変動が認められる。

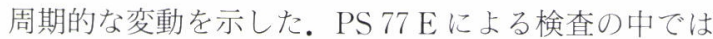
基本周波数や音圧よりも呼気流率の方が変動が大きか った。

表 3 に各症例の測定結果を示した。聴覚的重症度結 果と朗読時間，無音区間，無音区間比の間には有意の

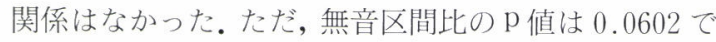
あり，危険率 $5 \%$ 以上であるが，重症度との間に相関 傾向があると推測できた。同様にモーラ法との関係を 検討したがやはり明らかな相関関係はなかった。図 5 は Jitter, Shimmer, SNR, STD-F 0 抢よび STD-Flow と聴覚的重症度結果を比較したグラフである. Shim$\operatorname{mer}(\mathrm{p}=0.0085), \operatorname{SNR}(\mathrm{p}=0.0019)$, STD-Flow $(\mathrm{p}=$ 0.0256）は重症度との間に相関関係が認められた。 STD-F 0 は P 值が 0.0513 であり相関傾向が認められ た.モーラ法との関係では, Shimmer $(\mathrm{p}=0.0121)$, SNR $(p=0.0413)$ と相関関係にあった. STD-Flow は $\mathrm{p}$ 值が 0.0566 であり相関傾向が認められた。

\section{3. 考察}

今回の研究はすでに記録されている音声サンプルを 用いて SD 患者の定量的な評価を試みたものである. 録音の際には読む速度に関して特別な指示を与えなか った。このことが朗読時間や無音区間の時間と聴覚的 重症度との間の関係が低かった理由の一つであろう. このような検査を行うためには音声サンプルを録音す る際に「出来るだけ速く朗読する」といった速度に関 する設定が必要である。呼気流量は目40ように SD 患者では大きく変動するパラメーターの一つであり， 非周期的な声带の緊張状態, 頸部の筋群や呼吸筋の過 緊張状態などに影響される. STD-Flow が重症度と相 
表 3 研究 2 の検查結果

\begin{tabular}{ccccccccccc}
\hline 症例 & 朗䛃時間 & 無音区間 & 無音区間比 & Jitter & Shimmer & SNR & STD F 0 STD Flow & 重症度 & モーラ法 \\
\hline $2-1$ & 4.172 & 0.827 & 0.198 & 0.304 & 2.519 & 23.194 & 3.037 & 28.065 & 1.5 & 5 \\
$2-2$ & 3.282 & 0.731 & 0.223 & 0.368 & 2.224 & 9.087 & 2.124 & 24.3 & 1.75 & 1 \\
$2-3$ & 3.731 & 1.235 & 0.331 & 0.817 & 3.663 & 6.462 & 38.456 & 55.93 & 3 & 11 \\
$2-4$ & 4.531 & 1.544 & 0.341 & 0.172 & 0.973 & 26.486 & 3.612 & 10.785 & 1.25 & 1 \\
$2-5$ & 5.039 & 1.951 & 0.387 & 2.394 & 3.09 & 9.965 & 6.104 & 34.125 & 2.5 & 14 \\
$2-6$ & 3.034 & 1.435 & 0.473 & 1.984 & 2.504 & 16.802 & 4.206 & 14.083 & 2.5 & 5 \\
$2-7$ & 5.072 & 1.544 & 0.304 & 0.359 & 2.027 & 10.832 & 1.95 & 11.787 & 1.75 & 3 \\
$2-8$ & 4.438 & 1.419 & 0.32 & 0.671 & 4.895 & 10.044 & 30.5 & 15.22 & 2 & 13 \\
$2-9$ & 3.799 & 1.266 & 0.333 & 0.065 & 1.09 & 18.806 & 2.054 & 14.539 & 1 & 0 \\
$2-10$ & 4.665 & 1.679 & 0.36 & 0.842 & 1.35 & 18.421 & 2.336 & 2.644 & 1.5 & 0 \\
$2-11$ & 5.844 & 1.721 & 0.294 & 0.584 & 2.026 & 20.462 & 2.864 & 20.23 & 1.5 & 3 \\
$2-12$ & 6.463 & 3.023 & 0.468 & 0.568 & 1.618 & 14.26 & 1.136 & 19.415 & 2 & 8 \\
$2-13$ & 5.015 & 3.061 & 0.61 & 0.317 & 3.999 & 4.128 & 11.442 & 103.345 & 3 & 10 \\
$2-14$ & 5.481 & 1.535 & 0.28 & 0.876 & 3.194 & 16.905 & 6.941 & 6.961 & 1.5 & 2 \\
$2-15$ & 8.069 & 3.947 & 0.483 & 0.602 & 3.462 & 12.622 & 24.2 & 206.6 & 2 & 2 \\
\hline
\end{tabular}

関関係にあったという結果は，SD 患者の持つ非周期 性や不均一などの特徵がわれわれが感じる重症度とい う尺度に関係して扔り，STD-Flow はこの特徵を反映 するパラメーターであるということを示唆している.

SD 患者では持続発声母音の Jitter や Shimmer が 高く, SNRが低いことはすでに報告されている15).今 回の研究からは Shimmer やSNR が重症度やモーラ 法と相関関係にあるという結果が得られた．SD 患者 の発声の特徴から SNR が有効であることは理解でき る.しかし, JitterやShimmer は細かいゆらぎを判定 するパラメーターであり，SD 患者の発声のように大 きく変動する音声評価には不向きであると考えられ る。それにもかかわらず Shimmer が有効という結果 が得られたことは興味深い。この結果には追試が必要 であるが，ShimmerやSNR は音響分析ソフトを用い れば簡単に検査することが可能であり，臨床的にも有 用なパラメーターとなりえる。

\section{研究 3 患者判定による主観的重症度評価}

\section{1. 評価案の作成および方法}

Arnold $^{2}$ は 1959 年に発表した論文の中で表 1 の項 目 4 のように SD は psychoneurosis な疾患であると 記載してある. 1970 年以前は SD は心因性発声障害と 考えられていたようである. Aronson は Clinical voice disorders ${ }^{3)}$ の中で, SD の原因は psychogenic, neurologic, or of unknown etiology であると述べて いる.現在では neurologic な疾患群に含まれるといわ れている。しかし，発症の様子を詳細に聞くと心因性
と考えられる症例が存在する.駿河台日本大学病院を 受診した AD-SD 患者の中で発症誘引として心因性と 推測できた例が 20 例中 5 例いた。 ただし，これらの例 でも病因が心因性であるか否かは不明であり，一種の 身体化表現とも考元られる.身体化表現とは他の原因 による疾患が心因的なきっかけにより発症することを 指す，発症のみならず症状の出現度合いも患者の精神 的状態や発話環境に左右される. また, 笑い声, ささ やき声, 歌声, 叫び声などでは声が出しやすくな る $2,26 \sim 30)$.このような理由により患者自身に重症度を 判定させる場合には, どのような環境でどのような発 声や会話をした時の状態について評価しなさいという 指示を与える必要がある。そこでわれわれは患者自身 による重症度評価案を作成する前に，「SD の会」の協 力を得てどのような場面で会話に支障があるかについ て会員の意見を聞いた。この意見を参考にして表 4 の ような評価案を作成した。この案は日常生活の支障度 と名づけ, 受動的な会話, 能動的な会話, 電話での会 話，返事などが含まれている.

東京大学耳鼻科音声外来を受診した SD 患者に日常 生活の支障度の評価案を渡し, 評点させた。同日録音 した音声サンプルを用いて 3 人の医師と 2 人の ST に より重症度評価とモーラ法による評価を行った。重症 度は研究 1 と同様に 0 から 3 の 4 段階評価法を採用し た。重症度と支障度はいずれも順序尺度であるために 相関関係の検証には研究 (2) と同様に Spearman の順 位相関法を用いた。 p 值はすべて Spearman 順位補正 後の $\mathrm{p}$ 值を表す. 

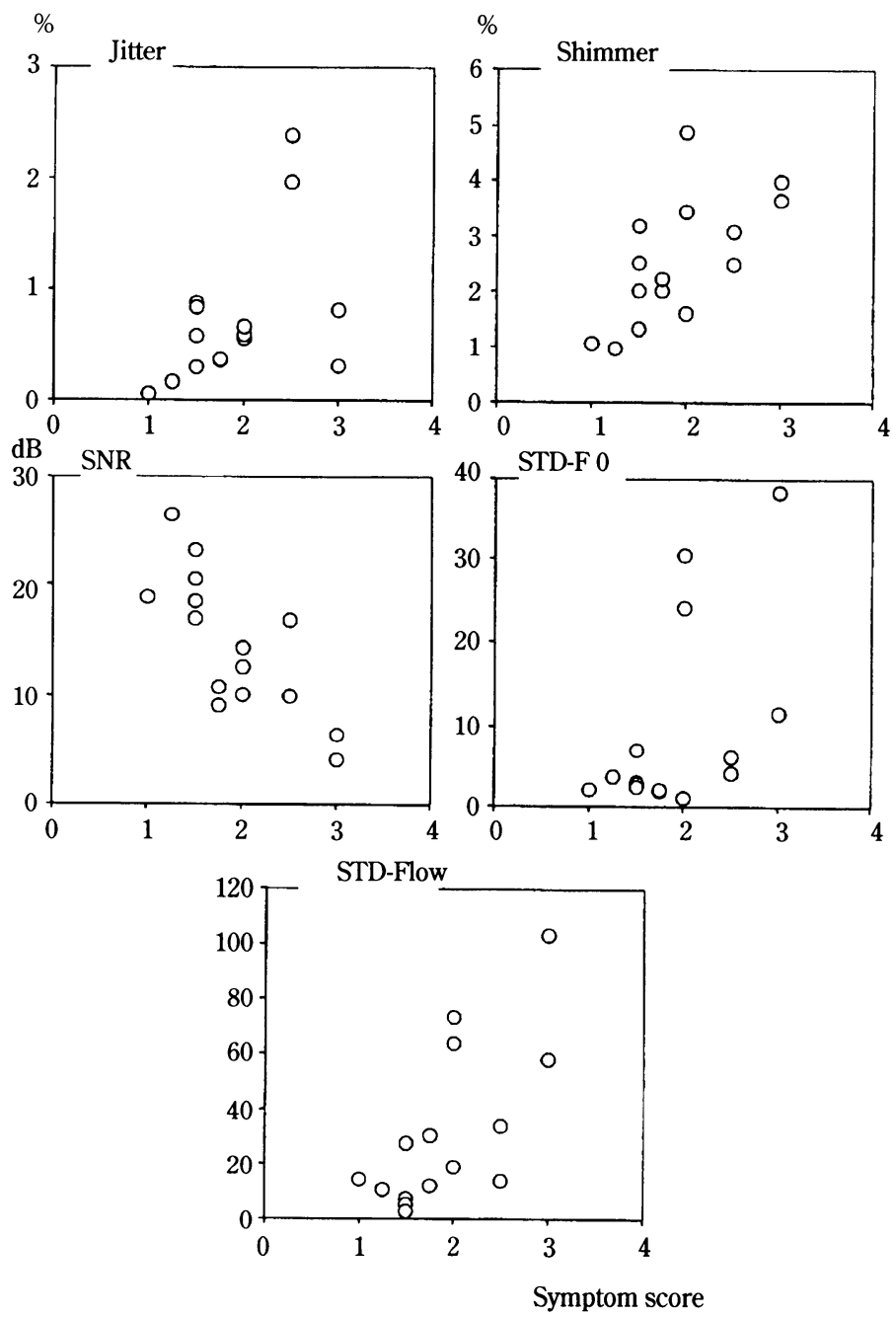

図 5 聴覚的重症度と Jitter, Shimmer, SNR, STD-F 0, STD-Flow との関係. Shimmer, SNR は危険率 $1 \%$ 以下で, STD-Flow は $5 \%$ 以下で重症度と相関関係が認められた。

\section{2. 結果}

表 5 に患者評価による日常生活の支障度, 医師判定 による重症度, モーラ法による評点結果を示す.日常 生活の支障度の各質問項目の平均值を検討すると, 質 問 $\mathrm{G}$ が最も点数が高かった. 質問 $\mathrm{B}, \mathrm{D}, \mathrm{L}$ の点数も高 かった。逆に点数が低かったのは質問 $\mathrm{K}$ の独り言をい うときであった。また，質問 I の笑うときや質問 $\mathrm{H} の$ 返事をするとき, 質問 $\mathrm{E}$ の家族との会話の場合なども 障害度は低かった。

重症度と支障度との関係を検討した。支障度の項目 $\mathrm{B}(\mathrm{p}=0.0044), \mathrm{D}(\mathrm{p}=0.0270), \mathrm{F}(\mathrm{p}=0.0283), \mathrm{A}$ $(\mathrm{p}=0.0352)$ と重症度との間に相関関係が認められ た。逆に，両者の関係が低かったのは G, J, I の項目
であった。同様にモーラ法と各質問項目との関係を検 討した. 関係が深かったのは B $(\mathrm{p}=0.0056), \mathrm{L}(\mathrm{p}=$ 0.0358) であった. $\mathrm{E}(\mathrm{p}=0.0556)$ や $\mathrm{F}(\mathrm{p}=0.0612)$ でもモーラ法との関係が深い傾向にあった。逆に, I, $\mathrm{H}, \mathrm{J}, \mathrm{C}, \mathrm{A}, \mathrm{G}$ などはモーラ法との関係が低かった。 $\mathrm{K}$ は 1 例を除いて支障度 0 であり, 重症度やモーラ法 との関係はなかった。

\section{3. 考察}

質問 $\mathrm{G}$ が最も点数が高かったことは，患者にとって 大きな声で会話する時のような場面での会話は困難で あることを示している. 質問 D は自分から知らない人 に電話をかける場合の支障度であるが, 質問 C の知ら ない人から電話がかかってきた場合より支障度が強か 
表 4 日常生活の支障度

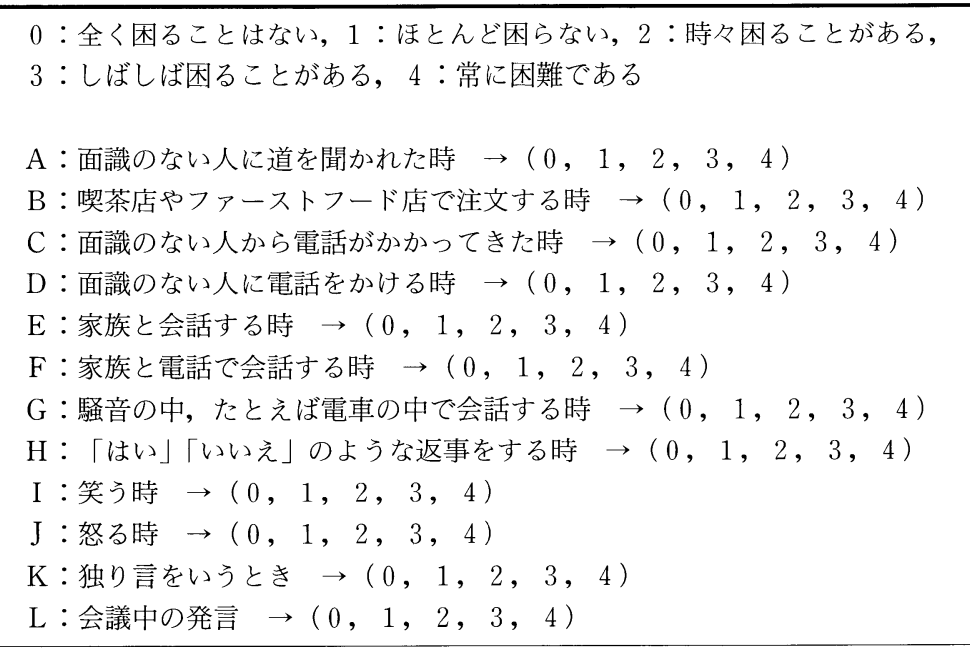

表 5 研究 3 の検查結果

\begin{tabular}{|c|c|c|c|c|c|c|c|c|c|c|c|c|c|c|c|}
\hline \multirow{2}{*}{ 症例 } & \multicolumn{12}{|c|}{ 日常生活の支障度 } & \multirow{2}{*}{ 平均 } & \multirow{2}{*}{ 重症度 } & \multirow{2}{*}{ モーラ法 } \\
\hline & $\mathrm{A}$ & $\mathrm{B}$ & $\mathrm{C}$ & $\mathrm{D}$ & $\mathrm{E}$ & $\mathrm{F}$ & $\mathrm{G}$ & $\mathrm{H}$ & I & $\mathrm{J}$ & $\mathrm{K}$ & $\mathrm{L}$ & & & \\
\hline $3-1$ & 2 & 3 & 3 & 3 & 2 & 2 & 3 & 3 & 0 & 3 & 1 & 3 & 2.33 & 2 & 19 \\
\hline $3-2$ & 1 & 3 & 1 & 3 & 1 & 1 & 3 & 2 & 0 & 2 & 0 & 4 & 1.75 & 2 & 10 \\
\hline $3-3$ & 3 & 3 & 4 & 4 & 1 & 2 & 3 & 1 & 1 & 1 & 0 & 4 & 2.25 & 2 & 6 \\
\hline $3-4$ & 2 & 3 & 2 & 3 & 2 & 3 & 3 & 2 & 0 & 3 & 0 & 4 & 2.25 & 3 & 25 \\
\hline $3-5$ & 2 & 2 & 3 & 3 & 2 & 2 & 4 & 1 & 0 & 2 & 0 & 3 & 2 & 0 & 0 \\
\hline $3-6$ & 4 & 4 & 3 & 3 & 2 & 2 & 4 & 1 & 0 & 0 & 0 & 4 & 2.25 & 3 & 25 \\
\hline $3-7$ & 0 & 1 & 0 & 0 & 0 & 0 & 4 & 0 & 4 & 4 & 0 & 3 & 1.33 & 0 & 1 \\
\hline $3-8$ & 1 & 1 & 0 & 0 & 0 & 0 & 3 & 0 & 3 & - & 0 & 0 & 0.73 & 0 & 2 \\
\hline $3-9$ & 1 & 1 & 1 & 1 & 0 & 1 & 2 & 0 & 0 & 1 & 1 & 1 & 0.83 & 1 & 0 \\
\hline $3-10$ & 1 & 3 & 2 & 3 & 2 & 2 & 4 & 0 & 0 & 2 & 0 & 3 & 1.83 & 1 & 25 \\
\hline $3-11$ & 2 & 2 & 2 & 3 & 1 & 1 & 3 & 3 & 0 & 1 & 0 & 1 & 1.58 & 1 & 1 \\
\hline $3-12$ & 1 & 1 & 1 & 1 & 1 & 1 & 1 & 1 & 0 & 0 & 0 & 1 & 0.75 & 0 & 0 \\
\hline 平均 & 1.67 & 2.25 & 1.83 & 2.25 & 1.17 & 1.42 & 3.08 & 1.17 & 0.67 & 1.73 & 0.17 & 2.58 & & 1.25 & 9.5 \\
\hline
\end{tabular}

った。質問 L は緊張した状態で大きな声を出さなけれ ばならないといった状況が推測され，この項目の障害 度が高いことは理解できる，独り言をいうとき，笑う とき，返事をするとき，などの点数は低かった。この 結果は, $\mathrm{Arnold}^{2}$ が報告した SD の特徵と一致する.知 らない人に比較して家族との会話の場合の方が障害度 は低かったが，たとえ家族が相手でも声のみがコミュ ニケーションの手段となる電話での会話では障害度は 高くなった。

支障度の項目 $\mathrm{B}, \mathrm{F}$ では重症度とモーラ法の両者と の関係が深かった。逆に項目 G，I，Jなどは両者との 関係が低かった。 $\mathrm{J}$ の怒る時や $\mathrm{G}$ の騷音の中での会話
ではたとえ軽症例でも支障度が高い場合があったＩ の笑うときに支障があると回答したのは 3 例のみであ り, 重症度やモーラ法との関係はなかった. $\mathrm{H}$ の返事 をする時も重症, 軽症に関係なく支障度に個人差があ った。このように外来診療時間内の様子だけで SD 患 者の日常の支障度を判断することはできない. 患者支 障度の調查は患者の把握という面からもきわめて有用 であった。

\section{今後の評価法}

表 6 は最近発表された SD に関する論文の中から， 重症度評価法を抜粋したものである. 大部分の論文は 
表 6 最近の文献で取り上げられた SD 患者の重症度評価

\author{
patients'self-ratings of voice quality ${ }^{31)}$ \\ $\mathrm{MPT}^{31-34)}$, 呼気流率 ${ }^{35)}$, 発声時口腔内圧 ${ }^{35)}$ \\ STD-F 0, Jitter, Shimmer および HNR ${ }^{31,32)}$ \\ 持続発声中の phonatory break の数や時間 $25,33,34,36)$ \\ 持続発声中の発声時間に対する phonatory break の時間比率 ${ }^{33,34)}$ \\ 持続発声開始から最初に phonatory break が出現するまでの時間 ${ }^{33)}$ \\ 各種の発声中に周期が変動した数や変動率 ${ }^{33,34)}$ \\ 持続発声開始から最初に周期が変動するまでの時間33) \\ 持続発声中の非周期的な segments の数 ${ }^{25,33)}$ \\ 文章朗読中に症状の出現した数 ${ }^{25}$ \\ 一分間に読むことのできる単語数や一息で話すことができる単語数 ${ }^{32}$
}

表 7 音声評価記録用紙

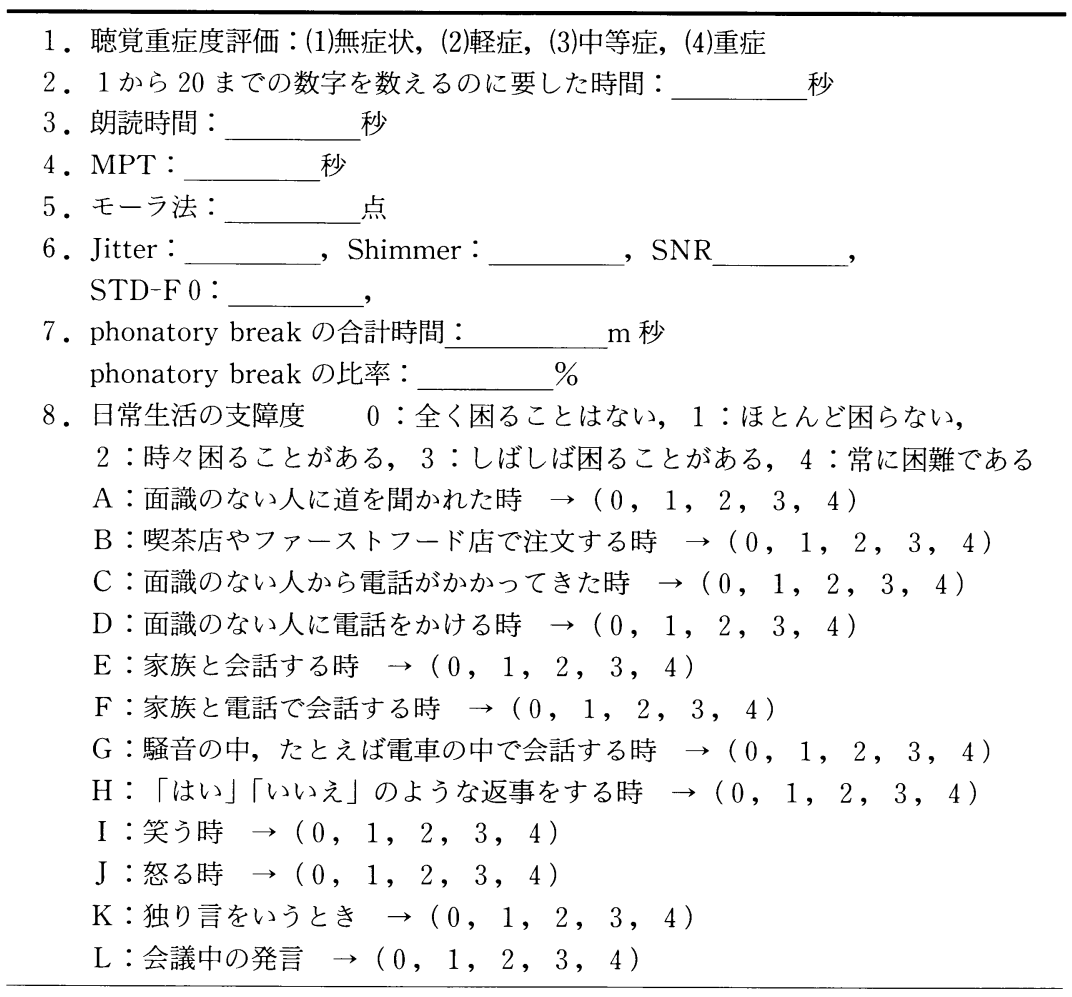

ボツリヌストキシン声帯筋内注入術の効果についての 報告であり，治療効果の判定のために各研究者が評価 法を工夫しているのが読み取れる。これらの大部分は われわれと同じような考え方で考案された評価法であ る. 結局, SD の重症度を直接評価する検査パラメータ 一はない.しかし，たとえ SDの一面のみ，たとえば流 暢性の障害度のみを反映する検査でも, 結果的に重症 度と深い関係にあれば, その検査は重症度評価の重要 な指標となりえる. 表 7 は今回の研究結果, 文献報告,
および外来検査としての簡便さを考慮して作成した $\mathrm{SD}$ の音声評価記録用紙である.今後も $\mathrm{SD}$ 検査の標準 化を目標にこれらの検査法について追試を行っていき たい.

本研究は駿河台日本大学病院, 東京大学医学部付属病院, 帝京 大学市原病院を受診した SD 患者さん達, 特に SD の会の会員の 協力で行われた. また, 東京大学の新美, 村野, 小西, 石毛の各 先生, 日本大学の島崎, 鈴木, 吉橋の各先生には聴覚的重症度評 
価やモーラ法の評価に協力していただいた。皆様に深謝いたしま す.

\section{文献}

1) Traube, L. : Spastishe Form der Nervosen Heiserkeit. In : Traube L, ed. Gesammelte zur Pathologie und Physiologie. Vol 2. Berlin : Hirschwald, pp. 674-678, 1871.

2) Arnold, G. E. : Spastic dysphonia : I. Changing interpretations of a persistent affliction. Logos, $2: 3-14,1959$.

3) Aronson, A. E. : Clinical voice disorders: An interdisciplinary approach 2 nd edition. Thieme Inc, New York, 1985, pp 157-197, 1985.

4) Wolfe, V. I., Bacon, M. : Spectrographic comparison of two types of spastic dysphonia. J Speech Hear Disord, 41:325-332, 1976.

5) Zwitman, D. H. : Bilateral cord dysfunctions: abductor type spastic dysphonia. J Speech Hear Disord, $44: 373-378,1979$.

6) Cannito, M. P., Johnson, J. P. : Spastic dysphonia : a continuum disorder. J Communication Disorder, 14:215-223, 1981.

7) Izdebski, K. : Overpressure and breathiness in spastic dysphonia: an acoustic (LTAS) and perceptual study. Acta Otolaryngol (Stockh), 97:373-378, 1984.

8) Ludlow, C. L., Naunton, R. F., Bassich, C. J. : Procedures for the selection of spastic dysphonia patients for recurrent laryngeal nerve section. Otolaryngol Head Neck Surg, $92: 24-31,1984$.

9) Hartman, D. E., Abbs, J. H., Vishwanat, B. : Clinical investigations of adductor spastic dysphonia. Ann Otol Rhinol Laryngol, 97 : 247252, 1988.

10) Merson, R. M., Ginsberg, A. P. : Spasmodic dysphonia : Abductor type. A clinical report of acoustic aerodynamic and perceptual characteristics. Laryngoscope, 89:129-139, 1979.

11) Aronson, A. E., Hartman, D. E. : Adductor spastic dysphonia as a sign of essential (voice) tremor. J Speech Hear Disord, 46:52-58, 1981.

12) Hartman, D. E., Aronson, A. E. : Clinical investigation of intermittent breathy dysphonia. J
Speech Hear Disord, 46 : 428-432, 1981.

13) Davis, P. J., Boone, D. R., Carroll, R. L., et al. : Adductor spastic dysphonia : Heterogeneity of physiologic and phonatory characteristics. Ann Otol Rhinol Laryngol, $97:$ 179-185, 1988.

14) Ludlow, C. L., Naunton, R. F., Sedory, S. E., et al. : Effects of botulinum toxin injections on speech in adductor spasmodic dysphonia. Neurology, $38: 1220-1225,1988$.

15) Makiyama, K., Bless, D. M., Ford, C. N. : Contrasts in voice characteristics with adductor and abductor spasmodic dysphonia. NCVS Status and Progress Report, $2: 139-155,1992$.

16）熊田政信，小林武夫，小崎寛子, 他：病卛性発声 障害の新しい評価法：モーラ法。音声言語医学, 38:176-181, 1997.

17) Blitzer, A., Brin, M. F., Fahn, S., et al. : Letter to the editor. Laryngoscope, $96: 1300-1301$, 1986.

18) Blitzer, A., Brin, M. F. : Treatment of spasmodic dysphonia (laryngeal dystonia) with local injections of botulinum toxin. J Voice, $6: 365-$ 369, 1992.

19) Ford, C.N., Bless, D. M., Patel, N.Y. : Botulinum toxin treatment of spasmodic dysphonia : Techniques, indications efficacy. J Voice, 6:370376, 1992.

20) Kobayashi, T., Niimi, S., Kumada, M., et al. : Botulinum toxin treatment for spasmodic dysphonia. Acta Otolaryngol (Stockh) Suppl, 504:155-157, 1993.

21）熊田政信，小林武夫，小崎寛子：痙攣性発声障害 に対するボツリヌストキシンの効果．音声言語医 学, 36：134, 1995.

22) Kumada, M., Bell-Berti, F., Kobayashi, T., et al. : The Syllable Method: The Proportion of Impaired Syllables as an Indicator of Spasmodic Dysphonia Severity. Folia Phoniatrica Logopaedia, Folia Phoniatr Logop, 53(1) : 1927, 2001.

23) Kumada, M., Bell-Berti, F, Honorof, D. N.: Comparing materials for the evaluation of symptom severity in the read speech of spasmodic dysphonia patients. CD-ROM of Collected Papers of $137^{\text {th }}$ Meeting of the Acoustical Society of America and $2^{\text {nd }}$ Convention of 
the European Acoustic Association. 4 ASCB-2, 1999.

24) Silverman, F. H. : Stuttering and other fluency disorders. Englewood Cliffts, NJ. 1992.

25) Cannito, M. P., Burch, A. R., Watts, C., et al. : Disfluency in spasmodic dysphonia : A multivariate analysis. J Speech Language Hearing Res, $40: 627-641,1997$.

26) Aronson, A. E., Brown, J.R., Litin, E. M., et al. : Spastic dysphonia I : voice, neurologic, and psychiatric aspects. J Speech Hear Disord, $33(3)$ : 203-218, 1968.

27) Bloch, C. S., Hirano, M., Gould, W. J. : Symptom improvement of spastic dysphonia in response to phonatory tasks. Ann Otol Rhinol Laryngol,94 (1) : 51-54, 1985.

28) Finitzo, T., Freeman, F. : Spasmodic dysphonia, whether and where: results of seven years of research. J Speech Language Hearing Res, 32 : 541-555, 1989.

29) Izdebski, K., Dedo, H. H. : Selecting the side of recurrent laryngeal nerve section for spastic dysphonia. Otolaryngol Head Neck Surg, 89(3) : 423-436, 1981.

30) Ludlow, C. L., Connor, N. P. : Dynamic aspects of phonatory control in spasmodic dysphonia. $\mathrm{J}$ Speech Language Hearing Res, 30:197-206, 1987.

31) Schonweiler, R., Wohlfarth, K., Dengler, R., et al. : Supraglottal injection of botulinum toxin type A in adductor type spasmodic dysphonia with both intrinsin and extrinsic hyperfunction. Laryngoscope, 108 : 55-63, 1998.

32) Crevier-Buchman, L., Laccourreye, O., Papon, J. F., et al. : Adductor spasmodic dysphonia: case reports with acoustic analysis following botulinum toxin injection and acupuncture. J Voice, 11(2) : 232-237 1996.

33) Sapienza, C. M., Murry, T., Brown, W. S. : Variations in adductoe spasmodic dysphonia : Acoustic evidence. J Voice, 12(2) : 214-222, 1998.

34) Sapienza, C. M., Walton, S., Murry, T. : Acoustic variations in adductor spasmodic dysphonia as a function of speech task. J Speech Language Hearing Res, 42 : 127-140, 1999.

35) Higgins, M. B., Chait, D. H., Schulte, L. : Phonatory air flow characteristics of adductor spasmodic dysphonia and muscle tension dysphonia. J Speech Language Hearing Res, 42:101-111, 1999.

36) Ludlow, C. L., Naunton, R. F., Swdory, M. A., et al. : Effects of botulinum toxin injections on speech in adductor spasmodic dysphonia. Neurol, $38: 1220-1225,1998$.

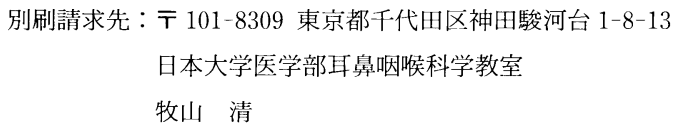

